\title{
Profile and birthing practices of Maranao traditional birth attendants
}

\author{
This article was published in the following Dove Press journal: \\ International Journal of Women's Health \\ 27 October 2015 \\ Number of times this article has been viewed
}

\author{
Roselyn Maghuyop-Butalid \\ Norhanifa A Mayo \\ Hania T Polangi \\ College of Nursing, Mindanao \\ State University-lligan Institute of \\ Technology, Iligan City, Philippines
}

Correspondence: Roselyn

Maghuyop-Butalid

College of Nursing, Mindanao State

University-Iligan Institute of Technology,

A. Bonifacio Avenue, Tibanga, 9200 lligan

City, Philippines

Tel +63927 6520398

Fax +63632232348

Email roselyn.butalid@g.msuiit.edu.ph

\begin{abstract}
This study determined the profile and birthing practices in both modern and traditional ways among Maranao traditional birth attendants (TBAs) in Lanao del Norte, Philippines. It employed a descriptive research design. The respondents were 50 Maranao TBAs selected through the snowball sampling technique. A questionnaire was developed by the researchers to identify the respondents' modern birthing practices utilizing the Essential Intrapartum and Newborn Care (EINC) Protocol. To determine their profile and traditional birthing practices, items from a previous study and the respondents' personal claims were adapted. This study shows that Maranao TBAs have less compliance to the EINC Protocol and they often practice the traditional birthing interventions, thus increasing the risk of complications to both mother and newborn.
\end{abstract}

Keywords: intrapartum and newborn care, modern birthing practices, traditional birthing practices

\section{Introduction}

In the effort to attain the Millennium Development Goals (MDGs) 4 and 5, which are to reduce child mortality and improve maternal health, respectively, ${ }^{1}$ the Department of Health (DOH) of the Philippines mandated the implementation of the Essential Intrapartum and Newborn Care (EINC) Protocol in both public and private hospitals in 2009 as supported by the World Health Organization (WHO). ${ }^{2}$ The EINC practices are evidence-based standards for safe and quality care of birthing mothers and their newborns within the 48 hours of the intrapartum period (labor and delivery) and 1 week of life for the newborn. These practices involve continuous support to the mother during labor and delivery by allowing a companion of choice, mobility and position of choice, nonpharmacologic pain management, and spontaneous pushing in the semi-upright position. The progress of labor is monitored using a partograph to detect obstructed labor and other complications. Episiotomy (perineal incision) is not done, unless necessary to prevent excessive perineal bleeding. Approaches in the management of the third stage of labor are shifted from physiologic to active, wherein the delivery of the placenta is hastened instead of waiting for its spontaneous delivery to reduce blood loss. ${ }^{2}$ Active management of third stage of labor (AMTSL) involves the injection of 10 units of oxytocin intramuscularly to the mother after the delivery of the baby, controlled cord traction (CCT) with counter traction on the uterus, and uterine massage. ${ }^{3}$ Recommended EINC practices for newborn care are time-bound interventions at the time of birth, which include immediate and thorough drying of the newborn, early skin-to-skin contact between mother and the newborn, properly timed cord clamping and cutting, and nonseparation between mother and newborn for early breastfeeding initiation. ${ }^{2}$ 
As the Philippine government and private birthing institutions are gradually implementing said protocol, pregnant women in the marginalized communities still entrust their birthing care to traditional birth attendants (TBAs). A TBA, as defined by the WHO, is a person who provides obstetric care services using acquired knowledge from other TBAs or through experience. ${ }^{4}$ Even nowadays, especially in developing countries, many community women still prefer the services of TBAs because they are always available as they live in the same community, sharing the same culture and beliefs, and mostly they are cheaper options compared to trained or professional health service providers. ${ }^{5}$

Maranao means "people of the lake", referring to the indigenous people who inhabited the grounds around Lake Lanao, Philippines. The Maranao is one of the last tribes in Mindanao adapting to modern society and not completely losing its ethnic identity. It is one of the largest Islamic groups in the Philippines. ${ }^{6}$ Infant delivery in remote Muslim communities is mostly handled by TBAs. ${ }^{7}$ In an attempt to determine the quality of birthing services the Maranaos in the far-flung areas are receiving, this study was conducted to determine the profile and birthing practices among Maranao TBAs to assess if their birthing interventions are safe and compliant with the ideal interventions set by the $\mathrm{DOH}$.

\section{Methodology}

The study used a descriptive research design to determine the respondents' profile and birthing practices, both modern and traditional. The sample of this study consisted of 50 Maranao TBAs between 31 and 85 years old who had attended at least ten delivery cases, regardless of sex, education, occupation, source of learning skills, and recruitment, selected through the snowball sampling technique. Snowball sampling, also known as chain-referral sampling, is a non-probability sampling technique wherein existing study participants are asked to assist the researchers in identifying other potential subjects from their acquaintances since TBAs are not easy to locate.

A researcher-made survey tool was used to determine the respondents' modern birthing practices utilizing the EINC Protocol. To determine their profile and traditional birthing practices, items from a study by Saravanan et $\mathrm{al}^{5}$ and the respondents' personal claims therein. The questions were translated to the Maranao language and the instrument was pretested with ten Maranao TBAs not involved with the final conduct of the study and analyzed through Cronbach's alpha. Actual interaction with each respondent was done to secure written informed consent to participate in the study and to gather the needed information through an interview. To analyze the data gathered, frequency and percentage distribution and weighted mean were employed. The study was approved by the Institute Ethics Review Committee (IERC) of Mindanao State University-Iligan Institute of Technology (MSU-IIT) before its final conduct.

\section{Results and discussion Research objective I: to identify the respondents' profile}

As depicted in Table 1, the respondents are mostly between 51 and 60 years old, followed by the $61-70$ years age range. This implies that TBAs are predominantly older, thus perceived to have ample personal experiences in terms of taking care of a woman during pregnancy, labor, and delivery. Most of them are females, so they are more aware of what to expect and what are the special needs of the woman during labor and delivery. The majority of them had attended Islamic schools but were unable to attain formal education. These findings suggest that TBAs are generally older and non-literate women. The respondents do not have a stable occupation and are mostly hilot, or traditional touch therapists, who treat minor illnesses such as fever, coughs and

Table I Profile of the Maranao TBA respondents $(\mathrm{N}=50)$

\begin{tabular}{|c|c|c|}
\hline Response & $\begin{array}{l}\text { Number of } \\
\text { responses }\end{array}$ & Percentage \\
\hline \multicolumn{3}{|l|}{ Age (years) } \\
\hline $31-40$ & 5 & 10.0 \\
\hline $4 \mid-50$ & 11 & 22.0 \\
\hline $51-60$ & 14 & 28.0 \\
\hline $61-70$ & 13 & 26.0 \\
\hline 7I and above & 7 & 14.0 \\
\hline \multicolumn{3}{|l|}{ Sex } \\
\hline Male & 3 & 6.0 \\
\hline Female & 47 & 94.0 \\
\hline \multicolumn{3}{|l|}{ Education } \\
\hline None & 37 & 74.0 \\
\hline Elementary & 8 & 16.0 \\
\hline High School & 5 & 10.0 \\
\hline \multicolumn{3}{|l|}{ Occupation } \\
\hline Hilot (traditional touch therapist) & 25 & 50.0 \\
\hline Farmer & 11 & 22.0 \\
\hline Business woman & 3 & 6.0 \\
\hline Dressmaker & I & 2.0 \\
\hline None & 10 & 20.0 \\
\hline \multicolumn{3}{|l|}{ Source of learning skills } \\
\hline Senior family members & 27 & 54.0 \\
\hline Other TBAs & 23 & 46.0 \\
\hline \multicolumn{3}{|l|}{ Recruitment } \\
\hline Senior family members & 30 & 60.0 \\
\hline Other TBAs & 20 & 40.0 \\
\hline
\end{tabular}

Abbreviation: TBA, traditional birth attendant. 
colds, sprains, and some bone dislocations through alternative medicine massage. They just receive a small amount of money or agricultural products of any kind for their services. Furthermore, $54 \%$ of the respondents had acquired the skills in handling delivery from their senior family members and $46 \%$ from other TBAs, and none of them had acquired formal training from professional health personnel. Moreover, $60 \%$ of the respondents had been influenced and recruited by their senior family members and $40 \%$ by other TBAs to become birth attendants.

\section{Research objective 2: to determine the modern birthing practices of the respondents}

As shown in Table 2, the respondents practice the modern and ideal birthing interventions only sometimes. This implies that they have fair performance in terms of modern birthing interventions and their practices are not parallel with the safe and ideal birthing protocol set by DOH. Table 2 also shows that the only modern or ideal interventions that the respondents always practice are to wash their hands before handling delivery and encouraging the postpartum mothers to breastfeed their babies. Handwashing is very important to reduce transmission of pathogenic microorganisms to patients. This concept applies to all settings where health care is performed, such as home care by birth attendants. ${ }^{8}$ Encouraging mothers to breastfeed is a very good practice, since breastfeeding is not only beneficial to the health of the baby but also it develops the physical and emotional bond between mother and child and even helps the mother recover from childbirth more quickly. ${ }^{9}$

The respondents do not practice comfort measures to the mother during labor such as allowing her to move freely, do breathing exercises, or even have something to eat. Thus, exhaustion may result and possibly compromise the labor process. They have no observance of sterility, as they do not wear sterile gloves upon handling delivery. Health care providers must wear sterile gloves in order to avoid the risk of contamination with the patient's blood and other body fluids. ${ }^{10}$ Likewise, there is a risk of maternal and neonatal sepsis as there is no protection from microorganisms, which may come from the TBA's hands. Only sometimes, they practice keeping the baby warm and dry and putting the newborn in skin-to-skin contact with the mother; failure to follow these practices can predispose a baby to hypothermia. Hypothermia has been found to increase the risk of metabolic acidosis,

Table 2 Modern birthing practices of the Maranao traditional birth attendant respondents $(\mathrm{N}=50)$

\begin{tabular}{|c|c|c|}
\hline Statement & $\begin{array}{l}\text { Average } \\
\text { weighted value }\end{array}$ & Description \\
\hline $\begin{array}{l}\text { I. I provide comfort to the mother by teaching her breathing exercises to lessen the pain during labor. } \\
\text { (Pemb'gan ak'n ikapipiya ginawa so ina lagi do kapamangdao ron sa kaginawa piya-piya para makaito so sakit.) }\end{array}$ & 1.00 & Never \\
\hline $\begin{array}{l}\text { 2. I wash my hands before handling the delivery. } \\
\text { (Pogonaban ak'n so lima ak'n sa dap'n so kambawata.) }\end{array}$ & 3.68 & Always \\
\hline $\begin{array}{l}\text { 3. I wear sterile gloves upon handling the delivery. } \\
\text { (P'solot ako sa glabs igira a p'kambawataan ak'n so ina.) }\end{array}$ & 1.60 & Never \\
\hline $\begin{array}{l}\text { 4. I dry the baby thoroughly after birth. } \\
\text { (P'kamaraan ak'n so wata piya-piya mapasad miliyo ko ina.) }\end{array}$ & 2.20 & Sometimes \\
\hline $\begin{array}{l}\text { 5. I put the baby to the mother's abdomen for skin-to-skin contact. } \\
\text { (Ip'mb'tad ak'n so wata ko tiyan o ina iyan.) }\end{array}$ & 1.98 & Sometimes \\
\hline $\begin{array}{l}\text { 6. I cut the umbilical cord after the pulsations have stopped. } \\
\text { (Potol'n ak'n so pos'd o wata mada so pulso niyan.) }\end{array}$ & 1.00 & Never \\
\hline $\begin{array}{l}\text { 7. I inject oxytocin to the mother before the placenta is delivered. } \\
\text { (Pag injek ako sa oxytocin ko ina sa dap'n miliyo si inayanan o ina.) }\end{array}$ & 1.00 & Never \\
\hline $\begin{array}{l}\text { 8. I massage the hypogastrium/fundus after placental delivery. } \\
\text { (P'masahiin ak'n so tiyan o ina mapasad miliyo so inayanan.) }\end{array}$ & 3.04 & Often \\
\hline $\begin{array}{l}\text { 9. I encourage the mother to breastfeed the baby. } \\
\text { (Di ak'n di taroan so ina a pakasosoon iyan so wata iyan.) }\end{array}$ & 3.62 & Always \\
\hline $\begin{array}{l}\text { 10. I inject vitamin } \mathrm{K} \text { to the newborn. } \\
\text { (Pag injek ako sa Vit. } \mathrm{K} \text { ko wata.) }\end{array}$ & 1.00 & Never \\
\hline $\begin{array}{l}\text { II. I refer the baby or the mother to the health facility for any complications. } \\
\text { (Ipag refer ak'n so ina odi na so wata sa center/hospital igira ad'n a komplikasyon.) }\end{array}$ & 1.00 & Never \\
\hline $\begin{array}{l}\text { 12. I encourage the mother to bring the baby to the health center for immunization. } \\
\text { (Di ak'n di taroan so ina a owita niyan so wata sa center para sa bakuna.) }\end{array}$ & 1.00 & Never \\
\hline Overall mean & $\mathrm{I} .84$ & Sometimes \\
\hline
\end{tabular}

Notes: 1.00-1.74 (never = poor performance); I.75-2.49 (sometimes = fair performance); $2.50-3.24$ (often = good performance); 3.25-4.00 (always = best performance). 
jaundice, respiratory distress, hypoglycemia, pulmonary hemorrhage, and death, regardless of the newborn's weight and gestational age. ${ }^{11}$ The respondents do not consider the cord pulsations as they cut the umbilical cord immediately after the baby is born. The timing of cord clamping and cutting within 1-3 minutes after the delivery of the baby improves the iron status of the infant. ${ }^{12}$

The respondents also do not practice the injection of oxytocin because they do not know its importance and availability and they do not have the capacity to do it. They do not perform CCT and counter traction on the uterus to remove the placenta, since they wait for its spontaneous delivery. Nevertheless, they often practice fundal massage after the placental delivery. These interventions during the third stage of labor do not correspond to the recommendations of the WHO. In 2012, the WHO recommended AMTSL as prevention for postpartum hemorrhage, which has three components, namely: 1) intramuscular injection of a uterotonic, preferably oxytocin, to the mother after the delivery of the baby; 2) performing CCT to deliver the placenta; and 3) massaging the uterine fundus after placental delivery. With a trial to this approach, it was found that administration of a uterotonic is most important to reduce hemorrhage and CCT and that immediate fundal massage can be optional. ${ }^{3}$

The respondents do not perform the injection of vitamin $\mathrm{K}$ (clotting factor) to the newborn, as they do not have any idea about it, which puts the newborn at increased susceptibility to bleeding disorders. Intramuscular injection of vitamin $\mathrm{K}$ prophylaxis is safe and the drug of choice for the prevention of hemorrhagic disease of the newborn. ${ }^{13}$ The respondents never refer a mother or baby to a health facility for complications. TBAs are less likely to recognize most maternal complications. ${ }^{14}$ They also do not advise infant immunization, so the baby is not protected against infectious diseases. Immunization is very important for infants and children since they are vulnerable to infections, which may result in fatal complications. ${ }^{15}$ The poor performance of the modern birthing practices among the respondents thereby increases the risk of maternal and neonatal complications related to delivery.

\section{Research objective 3: to determine the traditional birthing practices of the respondents}

As depicted in Table 3, the respondents often practice the traditional ways in handling delivery. This implies that they adhere to the birthing practices passed on by their ancestors. The respondents often use fundal maneuver to push the baby out, which may result in maternal and newborn injuries and death. Fundal maneuver is the application of manual pressure to the uppermost part of the uterus directed toward the birth canal to assist spontaneous vaginal delivery and to avoid prolonged second stage of labor. Possible complications include uterine rupture, anal sphincter damage, newborn fractures or brain damage, and increased blood transfusion between the mother and her unborn baby, which may result in $\mathrm{Rh}$ sensitization and transmission of viral diseases from mother to baby. ${ }^{16}$

The respondents always practice umbilical cord milking (UCM) prior to the ligation and cutting of the cord shortly after birth. UCM is a safe procedure and improves hemoglobin and iron status at 6 weeks of life among term and

Table 3 Maranao traditional birth attendant respondents' traditional birthing practices $(\mathrm{N}=50)$

\begin{tabular}{|c|c|c|}
\hline Statement & $\begin{array}{l}\text { Average } \\
\text { weighted value }\end{array}$ & Description \\
\hline $\begin{array}{l}\text { I. I perform fundal maneuver. } \\
\text { (Pag hilot'n ak'n so tiyan o ina.) }\end{array}$ & 2.62 & Often \\
\hline $\begin{array}{l}\text { 2. I perform milking of the umbilical cord before cutting. } \\
\text { (Pagandog'n ak'n so rogo ko pos'd sii ko wata.) }\end{array}$ & 4.00 & Always \\
\hline $\begin{array}{l}\text { 3. I use sewing thread as cord tie. } \\
\text { (Pagosar ako sa tanor para inggok't ko pos'd.) }\end{array}$ & 4.00 & Always \\
\hline $\begin{array}{l}\text { 4. I use sharpened bamboo in cutting the umbilical cord. } \\
\text { (Pagosar ako sa katatar'man a bamboo sa kapotol sa pos'd.) }\end{array}$ & 4.00 & Always \\
\hline $\begin{array}{l}\text { 5. I wait for the placenta to deliver spontaneously. } \\
\text { (Di ak'n di p'nayawan so kiliyo o inayanan.) }\end{array}$ & 2.66 & Often \\
\hline $\begin{array}{l}\text { 6. I bathe the baby immediately after birth. } \\
\text { (Di ak'n di paygoan so wata mapasad miliyo ko ina iyan gagaan.) }\end{array}$ & 3.02 & Often \\
\hline $\begin{array}{l}\text { 7. I encourage the mother to feed the baby with the clear breast milk rather than the yellowish colostrum. } \\
\text { (Di ak'n di taroon ko ina a pakasosoon iyan so wata ko maputi I kolor.) }\end{array}$ & 1.96 & Sometimes \\
\hline Overall mean & 3.18 & Often \\
\hline
\end{tabular}


near-term neonates. ${ }^{17}$ Though UCM is associated with some benefits and no adverse effects in the immediate postnatal period in preterm infants (gestational age $<33$ weeks), still, further studies are warranted to assess the effect of UCM on neonatal and long-term outcomes. ${ }^{18}$ The respondents often practice the traditional method of ligating the umbilical cord before cutting by using sewing thread. Since the umbilical cord tends to shrink after birth, this type of ligature proves somewhat unreliable in preventing hemorrhage. The more usual method in developed countries currently is plastic or metal clamps, which produce safe, reliable constriction and have been very successful in preventing bleeding from the navel. ${ }^{19}$ Moreover, the respondents always use unsterile sharpened bamboo in cutting the umbilical cord, which increases the risk of neonatal tetanus, omphalitis, and sepsis. ${ }^{20}$

The respondents often wait approximately 30 minutes for the placenta to deliver spontaneously, which allows excessive blood loss, leading to a very serious complication: hemorrhage. This practice contradicts the AMTSL of the EINC protocol, which involves CCT with counter traction on the uterus after a strong uterine contraction, stimulated by intramuscular injection of 10 units of oxytocin. AMTSL decreases the length of the third stage of labor, average blood loss, number of postpartum hemorrhage cases, and need for blood transfusion. ${ }^{3}$ Furthermore, the respondents practice newborn bathing immediately after birth, which may cause hypothermia, disorientation resulting in altered crawling reflex, and removal of the natural protection from infection, such as the maternal bacteria and the vernix caseosa, which is a potent inhibitor of Escherichia coli. ${ }^{21}$ Although the majority of the respondents always encourage breastfeeding, there are those that sometimes advise discarding the colostrum, the breast milk produced during the early days postpartum, as perceived to be dirty because of its yellowish color, which can be associated with pus. Thus, such newborns miss the health benefits of colostrum. Colostrum has a yellow to orange color because of its many substances that protect the baby from infections. ${ }^{22}$

\section{Recommendations and conclusion}

The adherence to traditional birthing practices among the Maranao TBAs may be accounted for by the influence from their elderly family members and lack of formal training. The majority of the respondents have less compliance with the modern and ideal birthing interventions, thus increasing the risk of complications to both mother and newborn. This implies that health authorities must exert more effort in addressing this concern at the soonest possible time to decrease the incidence of maternal and neonatal morbidity and mortality. Therefore, it is recommended that provision of culture-sensitive training to TBAs and heightened health awareness programs to indigenous peoples be implemented to promote maternal and child health in marginalized communities.

\section{Disclosure}

The authors report no conflicts of interest in this work.

\section{References}

1. The Philippines Millennium Development Goals [webpage on the Internet]. Makati City: Philippine Statistics Authority-National Statistical Coordination Board. Available from: http://www.nscb.gov.ph/stats/ mdg/default.asp. Accessed October 17, 2015.

2. Essential Intrapartum and Newborn Care (EINC) Evidence-based Standard Practices [webpage on the Internet]. Manila: World Health Organization Western Pacific Region. Available from: http://www. wpro.who.int/philippines/areas/maternal_child_nutrition/newborn_ mother_care/einc_protocols. Accessed January 2, 2015.

3. Active Management of the Third Stage of Labour: New WHO Recommendations Help to Focus Implementation. World Health Organization, USAID, CHIP; 2012. Available from: https://www.k4health.org/sites/ default/files/PPH\%20Briefer\%20\%28AMTSL\%29\%20may2013_0. pdf. Accessed July 1, 2015.

4. World Health Organization. Traditional Birth Attendant. Geneva: World Health Organization; 1992. Available from http://apps.who.int/iris/ bitstream/10665/38994/1/9241561505.pdf. Accessed October 17, 2015.

5. Saravanan S, Turrell G, Johnson H, Fraser J. Birthing practices of traditional birth attendants in South Asia in the context of training programs. J Health Manag. 2010;12(2):93-121.

6. Maranao [webpage on the Internet]. Countries and their Cultures. Available from: http://www.everyculture.com/East-Southeast-Asia/ Maranao.html. Accessed January 9, 2015.

7. Seventh Legislative Assembly. Muslim Mindanao Autonomy Act No. 293. Cotabato City; 2012. Available from: http://armm. gov.ph/armm-content/uploads/2015/03/MMA_293_FREE_ BIRTH_2015_03_04_04_54_24_325.pdf. Accessed October 17, 2015.

8. World Health Organization. WHO Guidelines on Hand Hygiene in Health Care: First Global Patient Safety Challenge Clean Care Is Safer Care. Geneva: World Health Organization; 2009. Available from: http://www.who.int/gpsc/5may/tools/9789241597906/en/. Accessed February 26, 2015.

9. Benefits of Breastfeeding for Mom [webpage on the Internet]. Elk Grove Village: HealthyChildren.org; [updated August 20, 2015] Available from: https://www.healthychildren.org/English/ages-stages/ baby/breastfeeding/Pages/Benefits-of-Breastfeeding-for-Mom.aspx. Accessed May 10, 2015.

10. World Health Organization. Glove Use Information Leaflet. Geneva: World Health Organization; 2009. Available from: http://www.who. int/gpsc/5may/Glove_Use_Information_Leaflet.pdf. Accessed May 29, 2015.

11. Zayeri F, Kazemnejad A, Ganjali M, Babaei G, Khanafshar N, Nayeri F. Hypothermia in Iranian newborns. Incidence, risk factors and related complications. Saudi Med J. 2005;26(9):1367-1371.

12. Abalos E. Effect of timing of umbilical cord clamping of term infants on maternal and neonatal outcomes: RHL commentary [webpage on the Internet]. In: The WHO Reproductive Health Library. Geneva: World Health Organization; [last revised March 2, 2009]. Available from: http://apps.who.int/rhl/pregnancy_childbirth/childbirth/3rd_stage/ cd004074_abalose_com/en/. Accessed June 10, 2015. 
13. [No authors listed]. Vitamin K injection-best prevention for newborns. Paediatr Child Health. 2002;7(8):588-589.

14. Bailey PE, Szászdi JA, Glover L. Obstetric complications: does training traditional birth attendants make a difference? Rev Panam Salud Publica. 2002;11(1):15-23.

15. For Parents: Vaccines for Your Children [webpage on the Internet]. Atlanta: Centers for Disease Control and Prevention; [updated September 23, 2014]. Available from: http://www.cdc.gov/vaccines/ parents/infants-toddlers.html. Accessed December 12, 2014.

16. Verheijen EC, Raven JH, Hofmeyr GJ. Fundal pressure during the second stage of labour. Cochrane Database Syst Rev. 2009;(4):CD006067.

17. Upadhyay A, Gothwal S, Parihar R, et al. Effect of umbilical cord milking in term and near term infants: randomized control trial. $\mathrm{Am}$ J Obstet Gynecol. 2013;208(2):120.e1-e6.

18. Al-Wassia H, Shah PS. Efficacy and safety of umbilical cord milking at birth: a systematic review and meta-analysis. JAMA Pediatr. 2015; 169(1):18-25.
19. Anderson JM, Philip AG. Management of the umbilical cord: care regimens, colonization, infection, and separation. Neoreviews. 2004;5(4): e155-e163.

20. Herlihy JM, Shaikh A, Mazimba A, et al. Local perceptions, cultural beliefs and practices that shape umbilical cord care: a qualitative study in Southern Province, Zambia. PLoS One. 2013;8(11):e79191.

21. Sobel HL, Silvestre MA, Mantaring JB 3rd, Oliveros YE, Nyunt-U S. Immediate newborn care practices delay thermoregulation and breastfeeding initiation. Acta Paediatr. 2011;100(8):1127-1133.

22. Colostrum: Your Baby's First Meal [webpage on the Internet]. Elk Grove Village: HealthyChildren.org; [updated August 20, 2015]. Available from: https://www.healthychildren.org/English/ages-stages/baby/ breastfeeding/Pages/Colostrum-Your-Babys-First-Meal.aspx. Accessed May 10, 2015.

\section{Publish your work in this journal}

The International Journal of Women's Health is an international, peerreviewed open-access journal publishing original research, reports, editorials, reviews and commentaries on all aspects of women's healthcare including gynecology, obstetrics, and breast cancer. The manuscript management system is completely online and includes

\section{Dovepress}

a very quick and fair peer-review system, which is all easy to use. Visit http://www.dovepress.com/testimonials.php to read real quotes from published authors. 